Đorđević I., Češljar G., Eremija S., Hadrović S., Cirković-Mitrović T., Gagić-Serdar R., Rakonjac Lj. (2020): Analysis of the organization of protected species monitoring in Serbia. Agriculture and Forestry, 66 (1): $105-$ 113.

DOI: 10.17707/AgricultForest.66.1.11

\author{
Ilija ĐORĐEVIĆ*, Goran ČE ̌̌LJAR, Saša EREMIJA, \\ Sabahudin HADROVIĆ, Tatjana ĆIRKOVIĆ-MITROVIĆ, \\ Renata GAGIĆ-SERDAR, Ljubinko RAKONJAC ${ }^{1}$
}

\title{
ANALYSIS OF THE ORGANIZATION OF PROTECTED SPECIES MONITORING IN SERBIA
}

\section{SUMMARY}

Monitoring of protected species within protected areas (PA) is an important component of PA management. In addition to the framework that defines the basic preconditions for PA management and the financing mechanisms that ensure sustainable financing for PA, a structural component of PA management is monitoring of protected species and changes in PA over a long period of time. In Serbia, key monitoring is carried out by the Institute for Nature Conservation as well as by PA managers. This research aimed to identify the management practices utilized for monitoring PA by different groups of managers. To do so, the organization of monitoring of protected species was observed. The survey indicated that monitoring in most PA is conducted by a ranger service, and experts are only present when public enterprises manage national parks. A lack of databases was identified for most PA managers, except the public enterprise Vojvodinašume, and the problems related to reintroduction of species are mostly financial. Therefore, in the next period, it is necessary to improve this aspect of PA management by providing additional financial resources and better organizing the monitoring of protected species in Serbia.

Keywords: protected areas, protected species, monitoring, protected area managers, Serbia

\section{INTRODUCTION}

Organization of protected area (PA) management in Serbia includes complex interaction of different actors, rules and responsibilities which are usually interacting with sector of environment and forestry. Sustainable management of PA represents interaction of these two sectors, as well as involvement of different institutions which are coming from state or other management level. Rules and responsibilities are regulated by law and bylaw regulations, and can be on national, regional or international level. Organization

\footnotetext{
${ }^{1}$ Ilija Đorđević (corresponding author: ilija.djordjevic@forest.org.rs), Goran Češljar, Saša Eremija, Sabahudin Hadrović, Tatjana Ćirković-Mitrović, Renata Gagić-Serdar, Ljubinko Rakonjac, Institute of forestry, Kneza Višeslava 3, Belgrade, SERBIA

Notes: The authors declare that they have no conflicts of interest. Authorship Form signed online. 
of PA management includes management framework, structural characteristics of PA management and mechanisms of financing PA, while one of structural characteristics of PA management includes monitoring of protected species (Djordjevic, 2018). According to Law on nature protection (2009) this activity is defined as „....planned, systematic and continues monitoring of nature condition i.e. its biological, geological and landscape diversity“. Monitoring is carried out because the need of data collection of PA characteristics in different periods, assessment of current state and drawing conclusions about changes during that time (Yoccoz et al., 2001). Subject of the monitoring represents biological diversity (Curovic et al., 2011; Milosevic et al., 2019), changes in landscape, historical and cultural changes, land use and human activities, external factors and the impact of management policies and programs (Martinic, 2010). Protected areas ensure conservation of natural resources and contribute to maintaining the ecological balance in the region (Liogchii et al., 2017).

Reasons for monitoring can be scientific and managerial, scientific focus is solely on "... learning, developing and understanding of the behavior and dynamics of the monitoring system...", while managerial character is based on “... providing information related to management decisions" (Yoccoz et al., 2001). This is an important characteristic because “... monitoring that does not provide relevant information to decision makers is not useful for management and unnecessary because it uses human and fiscal resources, which may be directed elsewhere” (Rao et al., 2009). Also, climate change impact on flora has been receiving increasing attention throughout the world (Šimunić et al., 2019; Chivulescu et al., 2019). As one of the most important strategic, developmental and planning aspects of nature protection, Puzovic (2016) cites biodiversity monitoring as "... a way of looking at conditions, and above all, changes in the field of nature protection and biodiversity". Implementation of this monitoring should be done through the nature protection manager, who coordinates the protection and monitoring activities in the PA, while the supervisor monitors the situation and changes (Puzovic, 2008).

Today, the management of PA involves the presence of managers coming from the public and private sectors, and this has conditioned the process of decentralization, which has shifted the focus of PA management to managers who do not traditionally come directly from the public sector (Djordjevic et al., 2014; Djordjevic et al., 2019/a; Nonic et al., 2014). In this research, the PA refers to the areas that have been separated from traditional use and given to the management of individual legal entities. These legal entities comes from the private and public sectors and can be divided on the basis of "... who makes decisions and can be held responsible" (Borrini-Feyerabend et al., 2013). PA managers have a significant role to play, because the use of PA depends directly on their presence and the activities they carry out on the field.

In Serbia management of PA can be given both to public and private sector, while the biggest managers are coming from public sector. Within this sector, public enterprise (PE) "Srbijašume" and PE that manages national parks 
(PENP) are the biggest managers and traditional they are coming from forest sector (Djordjevic et al., 2014). Monitoring of protected species is carried out on the level of these PE, other PA managers, as well as by the different institutes (ex. Institute for nature conservation, Institute for biological research etc.) and different environmental NGO organizations.

The goal of this research includes determination of monitoring practices within different groups of PA managers, while subject of this research are structural characteristic of PA management i.e. monitoring practices. The purpose is to establish preconditions for improving of current monitoring in Serbia and develop proposal for its improvement.

\section{MATERIAL AND METHODS}

As a research method door-to-door survey was used to collect primary data. Collection of this data was carried out in the period December 2014 - Jun 2015. The survey consisted of three sets of questions (basic characteristics, structural characteristics and financing mechanisms). For this paper, only questions related to monitoring of protected species were used (questions on structural characteristics).

The population was determined on the basis of the PA Register (2012) from which 63 PA were selected. The criteria for the sample selection were: the existence of a PA manager ${ }^{2}$, PA size (areas smaller than 10 ha were excluded) and PA categories.

In order to test differences between different managers of PA, previously defined typology of PA managers was used (Djordjevic et al., 2014). Based on this typology, and collected answers from PA managers, the following groups of PA managers were formed: a) PE "Srbijašume" (PES); b) PE "Vojvodinašume" (PEV); c) PENPs ${ }^{3}$; d) other PE (OPE); e) other managers from the public sector (OPS) and f) the private sector (PrS) ${ }^{4}$ (Djordjevic et al., 2019/a; Djordjevic et al., 2019/b). Questionnaire was codded using SPSS software (ver. 21) (Pallant, 2011) and data were processed by each question using the descriptive statistics and the frequency analysis (Neumann, 2014). Furthermore, $\chi^{2}$ test of independence was used to determine statistically significant relation (Pallant, 2011). This research also included review and comparative analysis (Wunder et al., 2008; Keča, Marković, 2019) of the elements in the field of nature protection.

\section{RESULTS}

In order to test monitoring practices in Serbia, this research studied monitoring method, existence of databases of monitoring species, need for

\footnotetext{
${ }^{2}$ In Serbia, certain PA do not have a manager (Djordjevic et al., 2014)

${ }^{3}$ PE „NP Đerdap“, PE „NP Kopaonik“, PE „NP Fruska gora“ and PE „NP Tara“

${ }^{4}$ The PrS is not subdivided into smaller groups, but seen as one group, in order to be able to compare the characteristics of managers between the groups of mangers.
} 
reintroduction of different species and its problems, as well as the process of NATURA 2000.

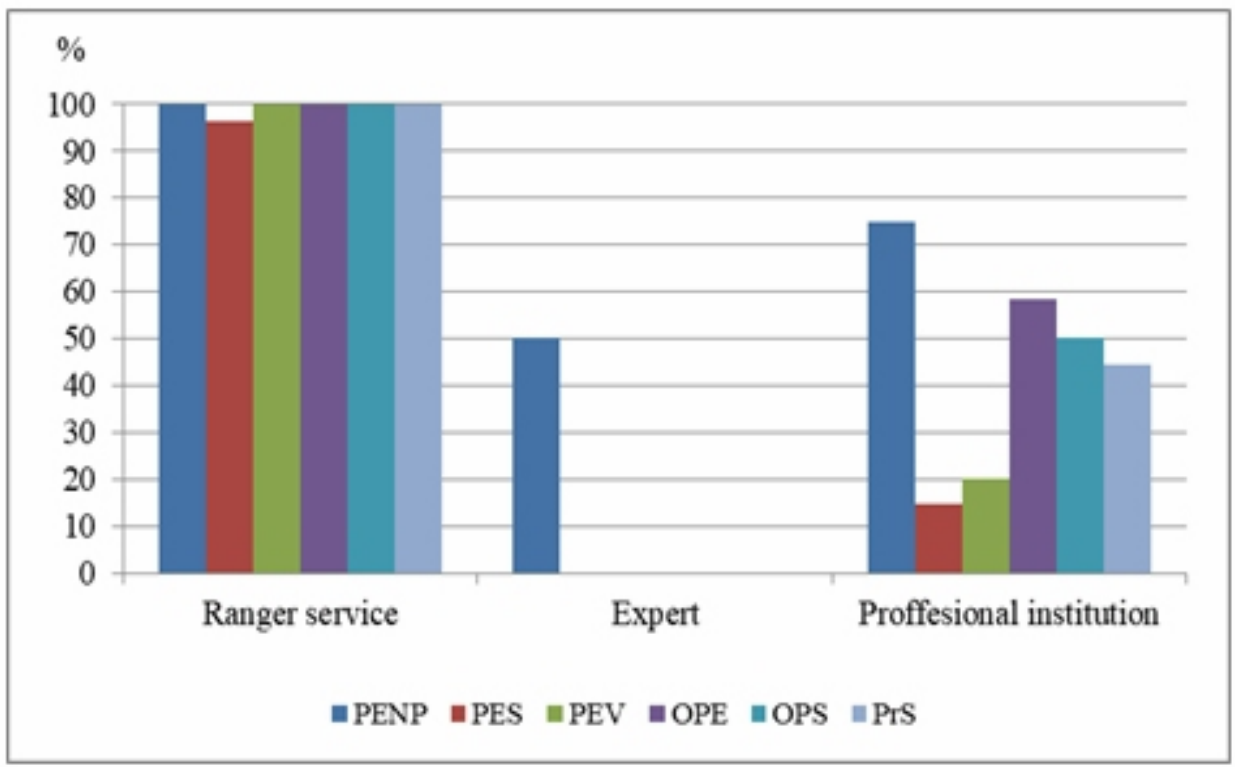

Figure 1. Monitoring method within different groups of managers



Figure 2. Databases on protected species within different groups of managers

Within this research, three types of monitoring methods were detected. Monitoring is carried by rangers, expert within manager and professional institution. As it can be seen in Figure 1 monitoring by an expert exists only in 
the PENP in half of the cases, while the professional institutions involved in monitoring are the highest in the PENP (75.0\%) and the least in the PE "Srbijašume"(14.8\%). Monitoring by ranger is mostly present as monitoring practice within all groups of managers. Using the $\chi^{2}$ independence test, a statistically significant relationship was found between the groups of managers and the monitoring method by an expert $(\chi 2=12.19$, df $=5, \mathrm{p}=0.03)$ and professional institutions $(\chi 2=12.38, \mathrm{df}=5 . \mathrm{p}=0.03)$, while no statistically significant relationship was found for monitoring by rangers $(\chi 2=1.72, \mathrm{df}=5, \mathrm{p}$ $=0.89)$. Effect size value $(\mathrm{V}=0.00)$, for $\mathrm{R}-1=1$ was assessed as small, when monitored by an expert, and when monitored by expert institutions, effect size value $(\mathrm{V}=0.04)$, for $\mathrm{R}-1=1$ is rated, also small.

Presence of databases are crucial for monitoring of species in long time period and Figure 2 shows these differences. It can be seen that in the PE "Vojvodinašume", in all cases the database exists, unlike other groups of managers. Also, by applying the $\chi 2$ independence test, a statistically significant relationship was found between the groups of managers and the presence of the database $\left(\chi^{2}=15.86 \mathrm{df}=5, \mathrm{p}=0.00\right)$. Effect size value $(\mathrm{V}=0.03)$, for $\mathrm{R}-1=1$, was considered small.

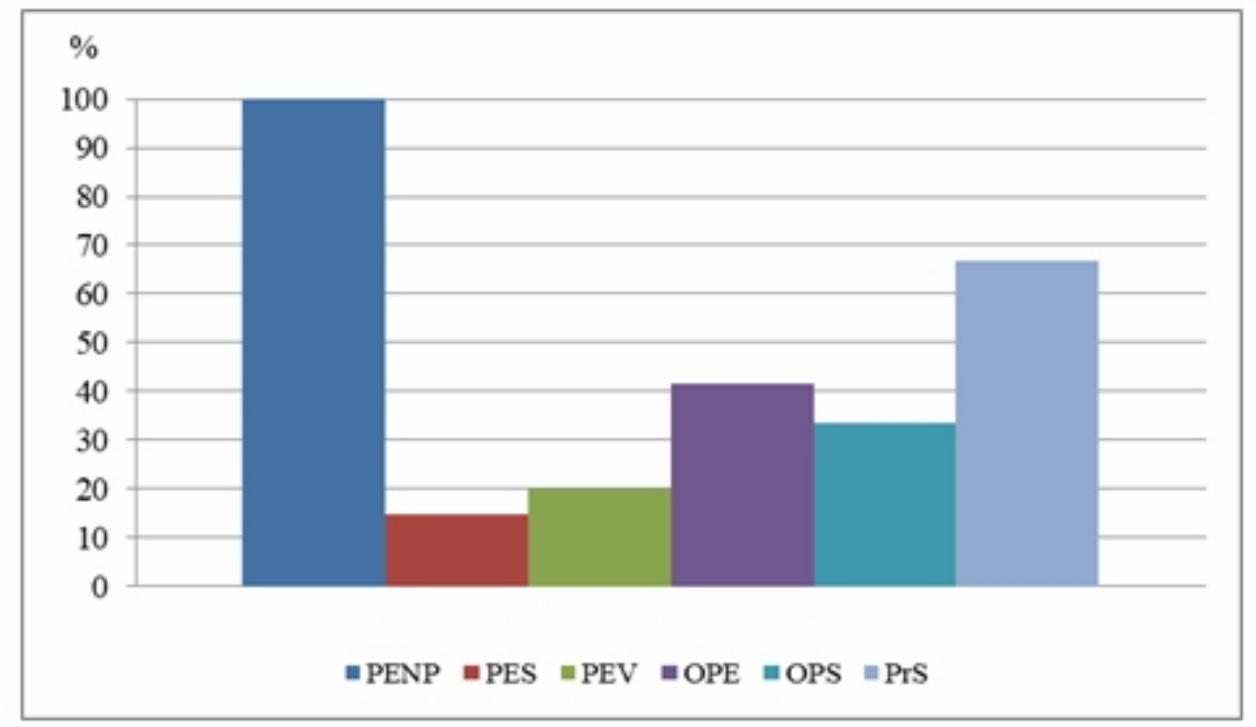

Figure 3. Need for species reintroduction within different groups of managers

Considering the need for reintroduction of certain species, it can be seen that it is completely present at PENP, unlike PE "Srbijašume" (Figure 3). Using the $\chi^{2}$ independence test, a statistically significant relationship was found between groups of managers and the need for reintroduction $(\chi 2=18.46, \mathrm{df}=5 \mathrm{p}$ $=0.00)$, and the effect size value $(\mathrm{V}=0.01)$ for $\mathrm{R}-1=1$ was estimated to be small. 


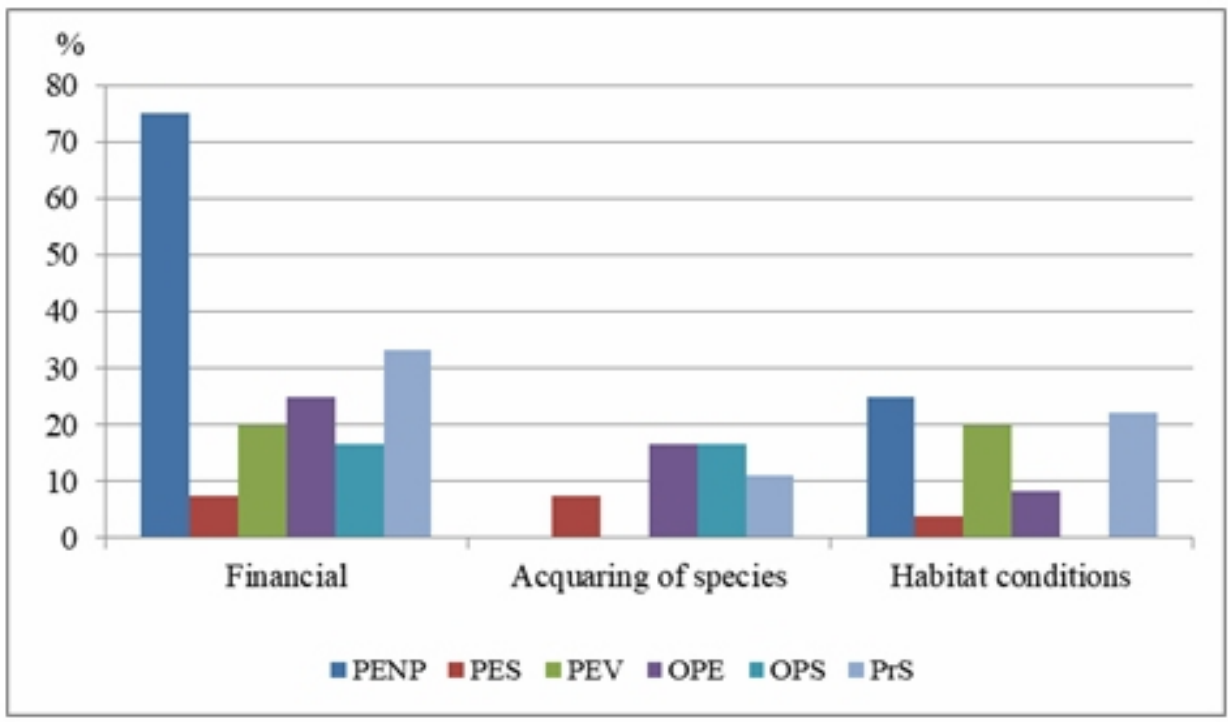

Figure 4. Problems in reintroduction within different groups of managers

In terms of type of problems (Figure 4), financial problems are the least present with PE "Srbijašume" (7.4\%), as opposed to PENP (75.0\%). Using the same test, no statistically significant relationship was found between groups of managers and financing problems $\left(\chi^{2}=10.02, \mathrm{df}=5, \mathrm{p}=0.08\right)$, which is the case for acquiring of species $\left(\chi^{2}=2.87, \mathrm{df}=5, \mathrm{p}=0.72\right)$ and habitat conditions $\left(\chi^{2}=\right.$ $5.15, \mathrm{df}=5, \mathrm{p}=0.40$ ).

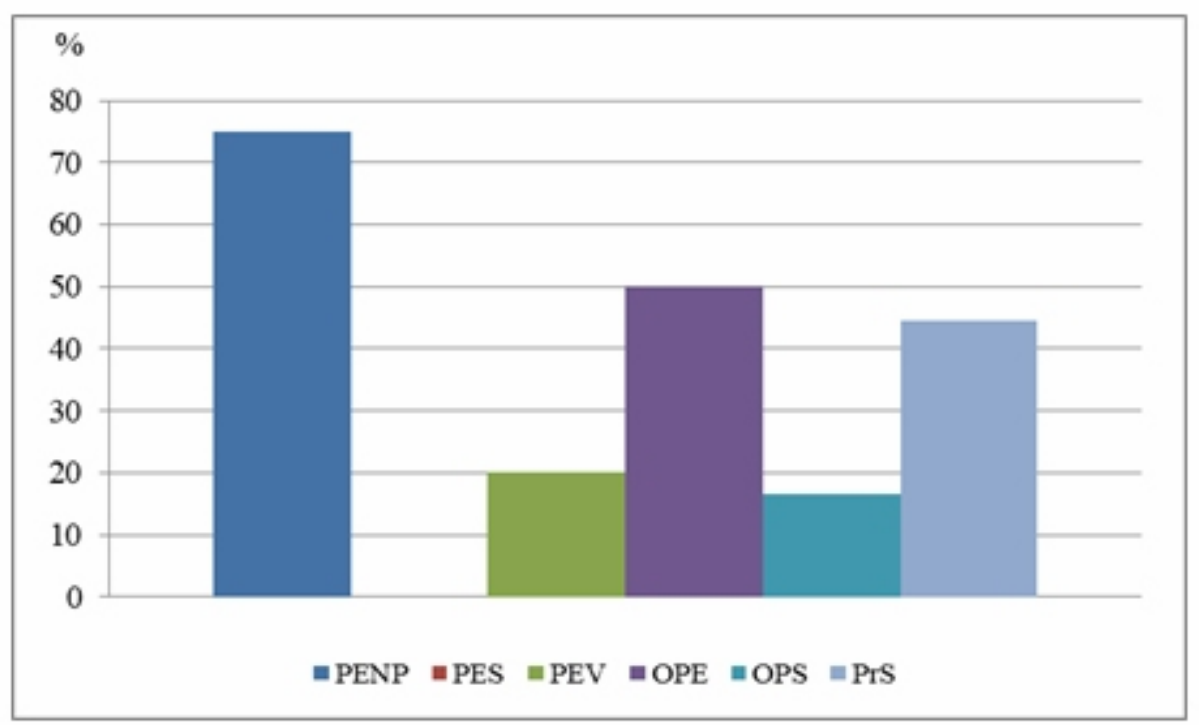

Figure 5. „Natura 2000” in PA within different groups of managers 
Identification of Natura 2000 started in in two thirds of cases within PENP, and none of the PA within the PE "Srbijašume" started this process (Figure 5). Using the $\chi^{2}$ independence test, a statistically significant relationship was found between the groups of managers and Natura $2000(\chi 2=25.25, \mathrm{df}=5, \mathrm{p}=0.00)$, and the effect size value $(\mathrm{V}=0.00)$, for $\mathrm{R}-1=1$ was rated small.

\section{DISCUSSION AND CONCLUSIONS}

Regarding to monitoring of protected species in Serbia, it was found that monitoring by an expert only exists in the PENP in half of the cases, while professional institutions are involved in monitoring, mostly within PENP and least within PE "Srbijašume”. Protected species databases are completely present in the PE "Vojvodinašume", unlike other groups of managers. All PENP have needs for reintroduction of plant and animal species, while the smallest need is within PE "Srbijašume", while the main problem of reintroduction is financial nature and is very pronounced in PENP. The Natura 2000 process has been started in most of PENP, unlike other groups of managers.

Research on the monitoring of protected species has been conducted within the methodology developed within the international organization IUCN. Thus, research in Slovenia indicates that almost all PA have monitored PA and that the current level of environmental research is appropriate and lacks socio-ecological research (Veenviet, Sovinc, 2008), as is the case with Croatia (Porej and Rajkovic., 2009), while in Serbia, the situation is completely opposite in terms of data collection and research on socio-ecological issues and processes in the PA environment (Piscevic, 2009).

In order to adequately perceive all changes occurring over a long period of time in the PA, it is necessary to introduce appropriate monitoring, however what has been done so far " ... is far from meeting the minimum needs and EU standards” (Puzovic, 2016). This author states that professional and scientific institutions do not have the appropriate financial resources to deal with this comprehensively and systematically, whereas the managers of the PA, to whom it is a legal obligation, are generally disinterested or without the professional and material capacity to implement it appropriately, except in rare case of NP and in the area of autonomous province of Vojvodina (Puzovic, 2016). The monitoring of protected species is carried out in all PA in Serbia, mostly through the ranger service of the PA, with the exception of the PENP, who in the half of the cases have an expert involved in these activities. Slovenia also monitors conditions in PA and the current level of environmental research is satisfactory (Veenviet and Sovinc, 2008). On the other hand, in Serbia there is a problem of continuous monitoring, of certain species of plants and animals, which is only carried out in individual cases by PENP. Also, there is a problem of lack of digital databases on protected species of plants and animals in all studied PA managers (exception is PE "Vojvodinašume”).

Proposals for improving of existing monitoring include the establishment of an additional organizational unit for monitoring of protected species at the 
level of the PA manager and external involvement of organizations/institution specialized in monitoring. One of the problems in realization of this activity could be limited financial and human capacities, so sustainable model of financing PA needs to be formed. Financing of PA by state should be separated in two directions, one dealing with running costs and other with the costs of improving and monitoring of PA. As a proposal for future research studies, it is suggested identification and analysis of the needs for monitoring of protected species, as well as the necessary organizational, human and financial capacities.

\section{ACKNOWLEDGEMENTS}

The research described in this paper was supported and financed by the Ministry of Science and Technological Development of the Republic of Serbia, Project TR 31070 "The development of technological procedures in forestry with a view to an optimum forest cover realization“(2011-ongoing).

\section{REFERENCES}

Borrini-Feyerabend G., Dudley N., Jaeger T., Lassen B., Pathak Broome N., Phillips A., Sandwith T. (2013): Governance of Protected Areas: From understanding to action, Best Practice Protected Area Guidelines Series No. 20, Gland. (124)

Chivulescu S, Leca S, Ciceu A, Pitar D, Apostol B (2019). Predictors of wood quality of trees in primary forests in the Southern Carpathians. Agriculture and Forestry, 65 (4): 101-113.

Curovic M, Stesevic D, Medarevic M, Cvjeticanin R, Pantic D, Spalevic V (2011). Ecological and structural characteristics of monodominant montane beech forests in the National Park "Biogradska Gora”, Montenegro. Arch Biol Sci 63 (2): 429440.

Djordjevic, I., 2018: Organizacija sistema upravljanja i tipovi upravljača zaštićenih područja u Srbiji, Disertacija, Šumarski fakultet Beograd

Djordjevic I., Nonic D., Nedeljkovic J. (2014): Management of protected areas in Serbia: Types and structure of managers, Agriculture \& Forestry, 60 (2), University of Montenegro - Biotechnical faculty, Podgorica. (7-26)

Djordjevic I., Nonic D., Nedeljkovic J., Tomicevic-Dubljevic J., Rankovic N., BrasanacBosanac Lj. (2019/a): Organization of the protected area management in Serbia: a comparative analysis of defined groups of managers, FEB - Fresenius Environmental Bulletin, Vol. 28(7), 5075-5082., Freising.

Djordjevic I., Rankovic N., Nedeljkovic J., Tomicevic-Dubljevic J., Nonic D., Posavec S., Cesljar G. (2019/b): Mechanisms of financing the protected area management system in Serbia, Journal of Forestry (in press)

Keca Lj., Markovic A. (2019) Payments for ecosystem services and stakeholder's perspectives in Serbia, Agriculture \& Forestry, 65 (1), Podgorica, 89-97.

Law on Environmental Protection (2009): Official Gazette of Republic of Serbia. no. 36/09, 88/10, 91/10 and 14/16, Belgrade.

Liogchii N., Begu A., Brega V. (2017): Status and role of natural ecosystems in north region of the Republic of Moldova, Agriculture \& Forestry 63 (1), University of Montenegro - Biotechnical faculty, Podgorica. (51-60)

Martinic I. (2010): Upravljanje zaštićenim područjima prirode, Planiranje, razvoj i održivost, Sveučilište u Zagrebu - Šumarski fakultet, Zagreb. (367) 
Milosevic, R., Curovic, M., Novakovic-Vukovic, M. (2019): Analysis of the floristic composition of mountain beech forests on the territory of Serbia and Montenegro. Fresenius Environmental Bulletin 28 (8): 5727-5733

Neuman W.L. (2014): Qualitative and Quantitative Approaches, 7th edition, Pearson Inc., Harlow, 599.

Pallant J. (2011) SPSS survival manual: A step by step guide to data analysis using the SPSS program. 4th Edition, Allen \& Unwin, Berkshire.

Piscevic N. (2009): Metodologija brze procene i prioritizacija upravljanja zaštićenim područjima (RAPPAM), Ministarstvo zaštite životne sredine - Republika Srbija i Mediteranski program WWF, Beograd. (41)

Porej D., Rajkovic Z. (2009): Effectiveness of Protected Area Management in Croatia: Results of the First Evaluation of Protected Area Management in Croatia Using the RAPPAM Methodology, Ministry of Culture of the Republic of Croatia, Zagreb. (57)

Protected Areas Register (2012): Institute for Nature Conservation of Serbia, internal document

Puzovic S. (2016): Strategic, developmental and planning aspects of nature protection, 2 Symposium on nature protection with international participation, Institute for nature conservation of Vojvodina province, Novi Sad. (27-37)

Puzovic S. (2008): Conservation and management of protected areas in Serbia, Protection of nature 60 (1-2), Institute for nature conservation of Serbia, Belgrade. (17-26)

Rao M., Stokes J.E., Johnson A. (2009): Monitoring for Management of Protected Areas - An Overview, Module 6. (116)

Simunic I., Likso T., Miseckaite O., Orlovic-Leko P., Ciglenecki I., Spalevic V. (2019): Climate changes and soil water regime, Agriculture \& Forestry 65 (3), 5-18

Veenviet K.J., Sovinc A. (2008): Protected area management effectiveness in Slovenia, Final report of the RAPPAM analysis, Ministry of the Environment and Spatial Planning of the Republic of Slovenia and WWF Mediterranean Programme. (56)

Wunder, S., Engel, S., Pagiola, S. (2008) Taking stock: A comparative analysis of payments for environmental services programs in developed and developing countries. Ecological economics, 65(4), 834-852.

Yoccoz G.N., Nichols D.J., Boulinier T. (2001): Monitoring of biological diversity in space and time, Trends in Ecology \& Evolution 16 (8), Cell press, Cambridge. (446-453) 